\title{
Malignant Pleural Mesothelioma in Young People
}

\author{
Ahmed El Bastawisy ${ }^{*}$, Maha Yahia1, Mohammed Rahouma², Omnia Aboelazm¹, \\ Jaylan Ahmed ${ }^{3}$
}

\author{
${ }^{1}$ National Cancer Institute, Cairo University, Cairo, Egypt \\ ${ }^{2}$ Weill Cornell Medicine, New York, USA \\ ${ }^{3}$ Baheya Cancer Center, Giza, Egypt \\ Email: *a_s_basta@hotmail.com
}

How to cite this paper: El Bastawisy, A., Yahia, M., Rahouma, M., Aboelazm, O. and Ahmed, J. (2017) Malignant Pleural Mesothelioma in Young People. Journal of Cancer Therapy, 8, 443-451. https://doi.org/10.4236/jct.2017.85038

Received: March 4, 2017

Accepted: May 21, 2017

Published: May 26, 2017

Copyright ( $\odot 2017$ by authors and Scientific Research Publishing Inc. This work is licensed under the Creative Commons Attribution International License (CC BY 4.0).

http://creativecommons.org/licenses/by/4.0/ (c) (i) Open Access

\begin{abstract}
Background: malignant pleural mesothelioma (MPM) is characterized by long latency period between exposure to asbestos and development of the disease so we hypothesize that MPM in the young has different characteristics. Patients and Methods: This is a retrospective study including all eligible patients with malignant pleural mesothelioma presenting to National Cancer Institute, Cairo University during the period from 2008 to 2013. Patients were divided into two groups: Group 1: patients aged $\leq 45$ years. Group 2: Patients aged $>45$ years. Both groups were assessed regarding different clinicpathological features. Primary Objectives: comparison of different epidemiological features of both groups. Secondary Objectives: assessment of clinical response (CR), progression free survival (PFS) and overall survival (OS) in both groups. Results: 102 Patients were included with median follow up of 14.4 months. Group (1) included 35 patients with mean age $40 \pm 3.65$ years ( 31 to 45 years). Group (2) included 67 patients with mean age of $58.6 \pm 8.5$ years ( 46 to 87 years). $68 \%$ of group (1) came from endemic areas which is significantly higher than group (2): (35.8\%), $\mathrm{p}=0.02$. History of Asbestos exposure was highly significantly different between the 2 groups, $77.1 \%$ in group (1) versus $38.8 \%$ in group (2), $\mathrm{p}<0.001$. Other factors showed no significant differences between the two groups. Overall clinical response (CR + PR) was $20 \%$ in group (1) versus $17.9 \%$ in group (2). $\mathrm{P}=0.7$. There was a trend towards longer median PFS in young patients, $(19.8 \pm 8.4$ versus $6.9 \pm 1.4$ months $) \cdot \mathrm{p}=0.09$. The median OS of young patients is significantly longer (20.6 \pm 6.3 months) than older patients $(11.4 \pm 3.6) \cdot \mathrm{p}=0.05$. Conclusions: Mesothelioma in the young is more sensitive to asbestos exposure, has better OS and likely a different disease entity which needs further studies to understand its underlying biological features.
\end{abstract}




\section{Keywords}

Malignant Pleural Mesothelioma-Young

\section{Introduction}

Mesothelioma is a rare cancer that is estimated to occur in approximately 2500 people is US every year [1].

Malignant pleural mesothelioma is the most common type, however, it can also occur in lining of other sites e.g. peritoneum, pericardium, tunica vaginalis testis.

Malignant pleural mesothelioma is the most common type, however, it can also occur in lining of other sites e.g. peritoneum, pericardium, tunica vaginalis testis. [2].

Repeated episodes of inflammation and healing, oxygen free radical production from inflammatory cells and the iron moiety within asbestos as well as direct damage to DNA by the fibers are generally accepted pathogenic features of asbestos exposure, this was the basis of a number of studies assessing prognostic factors like Neutrophil lymphocyte (N/L) ratio [3] [4] [5] [6] [7].

Treatment modalities in MPM are:

1) Surgery with radiation

2) Chemotherapy

3) or all three modalities

Recently, the standard treatment regimen for unresectable MPM:

1) Cisplatin plus pemetrexed as first line, 2) Second line chemotherapy may include single-agent pemetrexed (if not used with cisplatin for first-line therapy), Gemcitabine, or vinorelbine.

Malignant pleural mesothelioma occurs mainly in older men (median age is 72 years) who have exposed to asbestos although it occurs decades after exposure (20 to 40 years later) [3] [4] [5] [6].

Considering the long latency period from exposure to asbestos to disease development it is hypothesized that malignant pleural mesothelioma in young age is less likely to be caused by asbestos exposure and that other factors may attribute to the disease process such as genetic predisposition or exposure to other environmental carcinogens.

So it is important to understand the clinico-pathological features of malignant pleural mesothelioma in this particular age group.

\section{Aim of Work}

Primary objectives:

Assessment of different epidemiological features of malignant pleural mesothelioma in patients aged less than or equal 45 years as compared to those more than 45 years. 
Secondary objectives:

Assessment of the clinical outcome including clinical response, progression free survival and overall survival in patients aged less than or equal 45 years compared to those more than 45 years.

\section{Methods}

This is a retrospective population study including all patients with histologically proven malignant pleural mesothelioma presenting to the National Cancer Institute Cairo University during the period from 2008 to 2013.

Patients were divided to two groups:

Group 1:

Patients with malignant pleural mesothelioma aged less than or equal to 45 years.

Group 2:

Patients with malignant pleural mesothelioma aged more than 45 years.

Both groups were compared according to the following:

Eastern Cooperative Oncology Group (ECOG) Performance status (PS)

Sex

Histology (epithelial, sarcomatoid, biphasic)

Grade

Stage

Laterality

Asbestos exposure

Other carcinogens exposure

Family history

Smoking

Choice of cancer directed therapies (surgery, chemotherapy, radiotherapy, palliative treatment)

Clinical outcome including complete response, progression free survival and overall survival.

\subsection{Study Assessment}

Evaluation was done according to the Modified RECIST (Response Evaluation Criteria in Solid Tumors) [8].

\subsection{Statistical Analysis}

Data was analyzed using SPSS win statistical package version 21 (SPSS Inc., Chicago, IL). Numerical data were expressed as mean and standard deviation or median and range as appropriate. Qualitative data were expressed as frequency and percentage.

Chi-square test (Fisher's exact test) was used to examine the relation between qualitative variables. For quantitative data, comparison between two groups was done using either student t-test or Mann-Whitney test (non-parametric t-test) as appropriate. A p-value $<0.05$ was considered significant. 
Kaplan-Meier method calculated all survival estimates. Other predictor and prognostic variables were related to survival using log rank test. $\mathrm{P}$ value was set significant at 0.05 level (Kleinbaum, 2005).

\section{Results}

102 Patients were included with median follow up of 14.4 months.

\subsection{Patients' Characteristics}

Table 1 shows patients characteristics.

Table 1. Patients' characteristics.

\begin{tabular}{|c|c|c|c|c|c|c|}
\hline & & \multicolumn{4}{|c|}{ age group 45} & \multirow{3}{*}{ P value } \\
\hline & & \multicolumn{2}{|c|}{$<$ or $=45$} & \multicolumn{2}{|c|}{$>45$} & \\
\hline & & Count & $\%$ & Count & $\%$ & \\
\hline \multirow{2}{*}{ SEX } & Female & 15 & $42.9 \%$ & 28 & $41.8 \%$ & \multirow{2}{*}{0.918} \\
\hline & Male & 20 & $57.1 \%$ & 39 & $58.2 \%$ & \\
\hline \multirow[t]{2}{*}{ Residence } & $\begin{array}{l}\text { Non Endemic } \\
\text { areas }\end{array}$ & 11 & $31.4 \%$ & 43 & $64.2 \%$ & \multirow[t]{2}{*}{0.002} \\
\hline & Endemic areas & 24 & $68.6 \%$ & 24 & $35.8 \%$ & \\
\hline \multirow{2}{*}{$\begin{array}{l}\text { Diabetes } \\
\text { Mellitus }\end{array}$} & No & 30 & $85.7 \%$ & 57 & $85.1 \%$ & \multirow{2}{*}{0.931} \\
\hline & Yes & 5 & $14.3 \%$ & 10 & $14.9 \%$ & \\
\hline \multirow{2}{*}{ Hypertension } & No & 33 & $94.3 \%$ & 57 & $85.1 \%$ & \multirow{2}{*}{0.17} \\
\hline & Yes & 2 & $5.7 \%$ & 10 & $14.9 \%$ & \\
\hline \multirow{2}{*}{ smoking status } & No & 19 & $54.3 \%$ & 35 & $52.2 \%$ & \multirow{2}{*}{0.844} \\
\hline & Yes & 16 & $45.7 \%$ & 32 & $47.8 \%$ & \\
\hline \multirow{2}{*}{$\begin{array}{l}\text { Asbestosis } \\
\text { exposure }\end{array}$} & No & 8 & $22.9 \%$ & 41 & $61.2 \%$ & \multirow{2}{*}{0.000} \\
\hline & Yes & 27 & $77.1 \%$ & 26 & $38.8 \%$ & \\
\hline \multirow{5}{*}{$\begin{array}{l}\text { Performance } \\
\text { status }\end{array}$} & 1 & 33 & $94.3 \%$ & 55 & $82.1 \%$ & \multirow{5}{*}{0.165} \\
\hline & 2 & 1 & $2.9 \%$ & 9 & $13.4 \%$ & \\
\hline & 3 & 0 & $0.0 \%$ & 2 & $3.0 \%$ & \\
\hline & 4 & 0 & $0.0 \%$ & 1 & $1.5 \%$ & \\
\hline & NA & 1 & $2.9 \%$ & 0 & $0.0 \%$ & \\
\hline \multirow{4}{*}{$\begin{array}{l}\text { Pathology } \\
\text { Type }\end{array}$} & B & 4 & $11.4 \%$ & 7 & $10.4 \%$ & \multirow{4}{*}{0.205} \\
\hline & E & 30 & $85.7 \%$ & 55 & $82.1 \%$ & \\
\hline & NA & 1 & $2.9 \%$ & 0 & $0.0 \%$ & \\
\hline & $S$ & 0 & $0.0 \%$ & 5 & $7.5 \%$ & \\
\hline \multirow{5}{*}{ Stage } & IB & 0 & $0.0 \%$ & 1 & $1.5 \%$ & \multirow{5}{*}{0.44} \\
\hline & III & 10 & $28.6 \%$ & 25 & $37.3 \%$ & \\
\hline & IV & 24 & $68.6 \%$ & 40 & $59.7 \%$ & \\
\hline & NA & 1 & $2.9 \%$ & 0 & $0.0 \%$ & \\
\hline & UNK & 0 & $0.0 \%$ & 1 & $1.5 \%$ & \\
\hline \multirow{2}{*}{ Laterality } & $\mathrm{L}$ & 13 & $37.1 \%$ & 26 & $38.8 \%$ & \multirow{2}{*}{0.87} \\
\hline & $\mathrm{R}$ & 22 & $62.9 \%$ & 41 & $61.2 \%$ & \\
\hline
\end{tabular}


Group (1) included 35 patients with mean age $40 \pm 3.65$ years ( 31 to 45 years). Group (2) included 67 patients with mean age of $58.6 \pm 8.5$ years (46 to 87 years).

$68 \%$ of group (1) came from endemic areas which is significantly higher than group (2): (35.8\%), $\mathrm{p}=0.02$. History of Asbestos exposure was highly significantly different between the 2 groups, $77.1 \%$ in group (1) versus $38.8 \%$ in group (2), $\mathrm{p}<0.001$. Other factors including sex, diabetes mellitus, Hypertension, smoking, PS, pathological type and laterality showed no significant differences between the two groups.

\subsection{Clinical Response}

Overall clinical response (CR + PR) was $20 \%$ in group (1) versus $17.9 \%$ in group (2). $\mathrm{P}=0.7$. Table 2 .

\subsection{PFS}

The median PFS of our study group $12.3 \pm 3.3$ months. PFS for the whole study group after 6 months was $60.5 \%, 12 \mathrm{~m}$ was $51.5 \%, 18 \mathrm{~m} 43.9 \%$

- PFS for for young pts after 6 months was $75.2 \%, 12 \mathrm{~m}$ was $64.8 \%, 18 \mathrm{~m}$ $45.3 \%$. While for older pts was after 6 months was 53.2\%, $12 \mathrm{~m}$ was 41\%, 18 $\mathrm{m} 37.7 \%$.

- There was a trend towards longer median PFS in young patients, $(19.8 \pm 8.4$ versus $6.9 \pm 1.4$ months). $\mathrm{p}=0.09$ (Figure 1 ).

\subsection{OS}

- The median OS of our study group $16 . \pm 2.5$ months. OS for the whole study group after 6 months was $79 \%, 12 \mathrm{~m}$ was $56 \%, 18 \mathrm{~m} 44.7 \%$

- OS for for young pts after 6 months was $84 \%, 12 \mathrm{~m}$ was $68 \%, 18 \mathrm{~m} 52 \%$. while for older pts after 6 months was 76\%, $12 \mathrm{~m}$ was 47\%, $18 \mathrm{~m} \mathrm{39 \% .}$

- The median OS of young patients is significantly longer (20.6 \pm 6.3 months $)$ than older patients $(11.4 \pm 3.6) \cdot \mathrm{p}=0.05$ (Figure 2 ).

\section{Discussion}

There are several studies that report different clinico-pathological data and prognostic factors in either elderly or young patients but this study represents one of

Table 2. Clinical response.

\begin{tabular}{|c|c|c|c|c|c|c|}
\hline & & \multicolumn{4}{|c|}{ Age group 45} & \multirow{3}{*}{$P$ value } \\
\hline & & \multicolumn{2}{|c|}{$<$ or $=45$} & \multicolumn{2}{|c|}{$>45$} & \\
\hline & & Count & $\mathrm{N} \%$ & Count & $\mathrm{N} \%$ & \\
\hline \multirow{4}{*}{$\begin{array}{c}\text { Overall } \\
\text { Response }\end{array}$} & CR & 1 & $2.9 \%$ & 2 & $3.0 \%$ & \multirow{4}{*}{0.509} \\
\hline & $\mathrm{PD}$ & 13 & $37.1 \%$ & 35 & $52.2 \%$ & \\
\hline & $\mathrm{RD}$ & 6 & $17.1 \%$ & 10 & $14.9 \%$ & \\
\hline & $\mathrm{SD}$ & 15 & $42.9 \%$ & 20 & $29.9 \%$ & \\
\hline
\end{tabular}




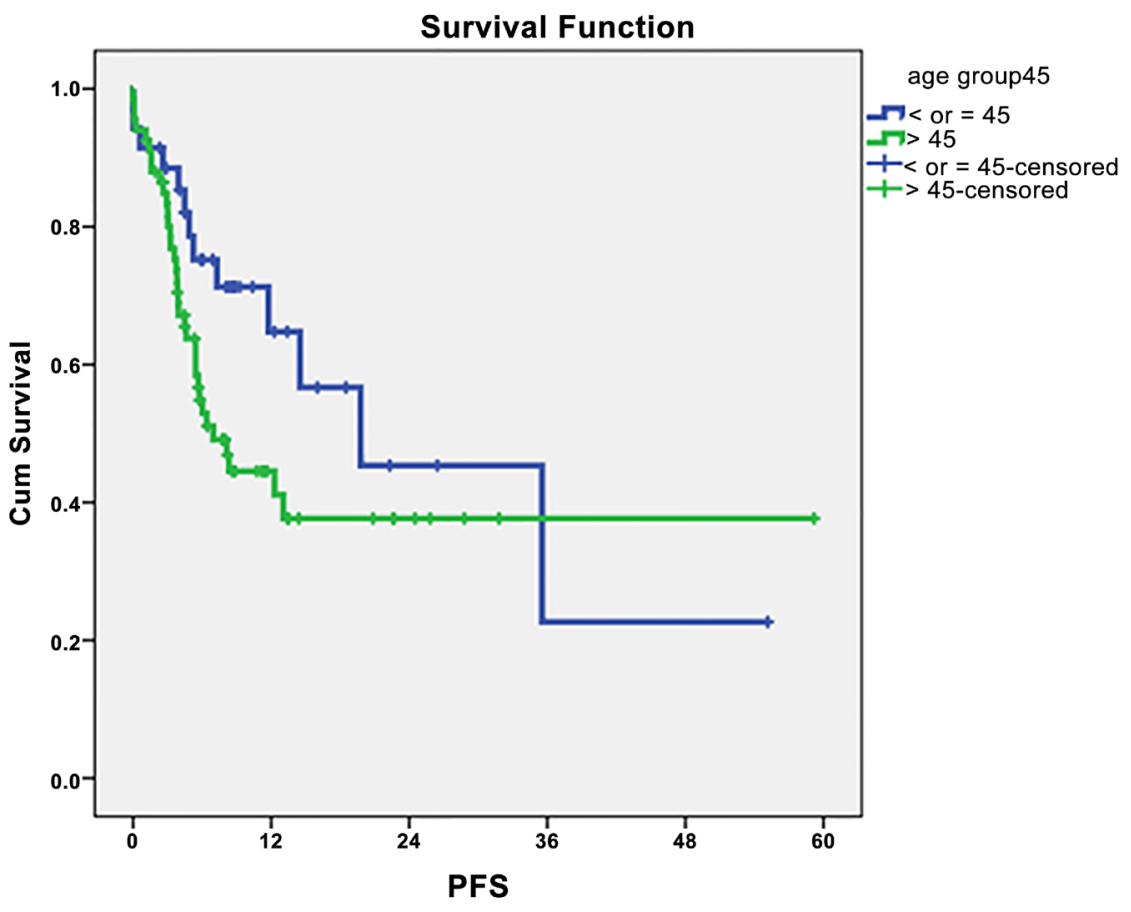

Figure 1. Progression free survival of both groups.

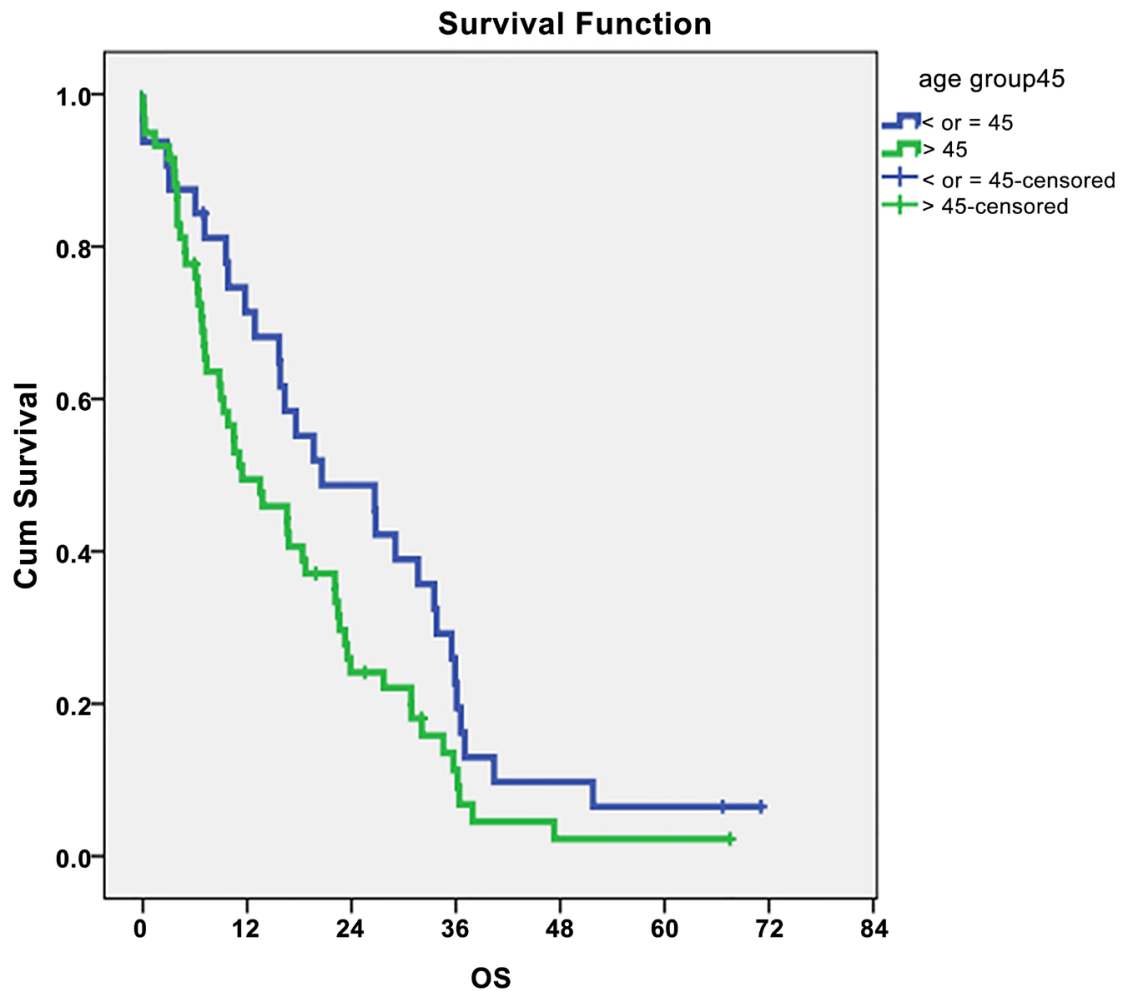

Figure 2. Overall survival of both groups.

the first studies that had been done in a comparative way between both cohorts, young and elderly MPM patients. [9] Hemdon et al. working on Cancer and Leukemia Group B (CALGB) treated patients reported young age to be a good 
prognostic factor for survival, however he assigned the cutoff value between young and elderly to be 75 years which lies near the upper age limit among our cohort. [10] Based upon that, we sought to divide our cohort around the median of 45 years old.

The most prevalent histological subtype was epithelial MPM, with male predominance among both cohorts, young and elderly, reflecting higher occupational exposure among men that are in concordance with many previously reported series [11] [12] [13].

It is well known that advanced stage is associated with poor PFS and overall survival in different thoracic malignancies; however, among our cohorts we couldn't find statistically significant stage differences among both cohorts [11] [12].

Effect of asbestos exposure and asbestosis is a cumulative one, hence several studies report higher incidence of asbestosis among elderly (76\% vs. nearly $40 \%$ in the current study). Although this is the usual due to the cumulative effect of asbestos exposure making those elderly group more vulnerable to MPM development, however among our cohort, we found that those young cohort might be heavily exposed to asbestos, evident by the higher percentage of endemic areas residents, that proved to be as important as long term low asbestos dose exposure [11] [12] [13] Again young patients maybe more sensitive to asbestos exposure whether occupationally or residentially which makes young patients more liable to develop mesothelioma regardless of the length of exposure, this may be attributed to unique biological factors characterizing this group of patients.

Advanced age is a well-known factor that is associated with poor overall survival in mesothelioma, whether pleural or peritoneal [11] and in other thoracic malignancy as lung cancer. Our median OS of 11.4 months in elderly is identical to that of the Italian multicenter study reported by Ceresoli et al. [11] On the other side, several studies reported better survival in younger patients with MPM and many of them attribute this to better performance status and absence of comorbidities and low level of reactive oxygen species implicated in aging process that are abundant among elderly population [11] [12] [13] [14] [15].

Also, our median PFS in elderly patient was concordant with other studies with median PFS of 8 months.

Many studies showed better response to chemotherapy in young MPM patients. Zucali et al. reported better PFS among young age group. [16] As we can see among our cohort, there was a trend towards longer median PFS in young patients, (19.8 versus 6.9 months) in elderly.

Based upon our results, MPM is represents a serious health problem in cohorts, young and elderly, so an integrated national and international commitment is required to eliminate it and other asbestos-related diseases.

Further studies are needed to identify a biological cut off point for definition of MPM in young patients.

The drawbacks of this study included small sample size, absence of a biologi- 
cal rational to the choice of age of young patients, being retrospective.

Further studies are needed to identify a biological cut off point for definition of MPM in young patients and to better understand the biological background of this disease entity including correlation with BAP1 and others.

\section{Conclusion}

Young mesothelioma patients are more significantly exposed to asbestos and coming more from endemic areas suggesting that mesothelioma in the young is more sensitive to asbestos exposure, again has better OS and likely a different disease entity which needs further studies to understand its underlying biological features.

\section{References}

[1] Price, B. and Ware, A. (2009) Time Trend of Mesothelioma Incidence in the United States and Projection of Future Cases: An Update Based on SEER Data for 1973 through 2005. Critical Reviews in Toxicology, 39, 576-588.

[2] Chekol, S.S. and Sun, C.C. (2012) Malignant Mesothelioma of the Tunica Vaginalis Testis: Diagnostic Studies and Differential Diagnosis. Archives of Pathology \& Laboratory Medicine, 136, 113-117.

[3] Bottomley, A., Coens, C., et al. (2007) Symptoms and Patient-Reported Well-Being: Do They Predict Survival in Malignant Pleural Mesothelioma? A Prognostic Factor Analysis of EORTC-NCIC 08983: Randomized Phase III Study of Cisplatin with or without Raltitrexed in Patients With Malignant Pleural Mesothelioma. Journal of Clinical Oncology, 25, 5770-5776.

[4] Utilization, G. and Unit, R. (2010) Clinical Practice Guidelines Mesotheliomna.

[5] Lanphear, B.P. and Buncher, C.R. (1992) Latent Period for Malignant Mesothelioma of Occupational Origin. Journal of Occupational Medicine, 34, 718-721.

[6] Selikoff, I.J., Hammond, E.C. and Seidman, H. (1980) Latency of Asbestos Disease among Insulation Workers in the United States and Canada. Cancer, 46, 2736-2740.

[7] El Bastawisy, A., Yahia, M., Rahman, A. and Gaafar, R. (2014) Prognostic Value of Neutrophil Lymphocyte Ratio in Second Line Advanced Malignant Pleural Mesothelioma. Journal of Cancer Therapy, 5, 717-722. https://doi.org/10.4236/jct.2014.57080

[8] Eisenhauer, E.A., Therasse, P., Bogaerts, B., Schwartz, L.H., Sargent, D., Ford, R., et al. (2009) New Response Evaluation Criteria in Solid Tumors: Revised RECIST Guideline (Version 1.1). European Journal of Cancer, 45, 228-247. https://doi.org/10.1016/j.ejca.2008.10.026

[9] Darnton, A., Hodgson, J., Benson, P. and Coggon, D. (2012) Mortality from Asbestosis and Mesothelioma in Britain by Birth Cohort. Occupational Medicine, 62, 549-552. https://doi.org/10.1093/occmed/kqs119

[10] Herndon, J.E., Green, M.R., Chahinian, A.P., Corson, J.M., Suzuki, Y. and Vogelzang, N.J. (1998) Factors Predictive of Survival among 337 Patients with Mesothelioma Treated between 1984 and 1994 by the Cancer and Leukemia Group B. Chest, 113, 723-731.

[11] Najmi, K., Khosravi, A., Seifi, S., Emami, H., Chaibakhsh, S., Radmand, G., et al. (2014) Clinicopathologic and Survival Characteristics of Malignant Pleural Mesothelioma Registered in Hospital Cancer Registry. Tanaffos, 13, 6-12. 
[12] Mensi, C., Sieno, C., De Matteis, S., Consonni, D., Riboldi, L. and Bertazzi, P.A. (2011) Incidence of Malignant Mesothelioma and Asbestos Exposure in the Lombardy Region, Italy 2000-2008. Giornale Italiano di Medicina del Lavoro ed Ergonomia, 33, 96-98.

[13] Van der Bij, S., Koffijberg, H., Burgers, J.A., Baas, P., Van de Vijver, M.J., de Mol, B.A.J.M. and Moons, K.G.M. (2012) Prognosis and Prognostic Factors of Patients with Mesothelioma: A Population-Based Study. British Journal of Cancer, 107, 161164. https://doi.org/10.1038/bjc.2012.245

[14] Davalli, P., Mitic, T., Caporali, A., Lauriola, A. and D’Arca, D. (2016) ROS, Cell Senescence, and Novel Molecular Mechanisms in Aging and Age-Related Diseases. Oxidative Medicine and Cellular Longevity, 2016, Article ID: 3565127. https://doi.org/10.1155/2016/3565127

[15] Neumann, V., Rütten, A., Scharmach, M., Müller, K.M. and Fischer, M. (2004) Factors Influencing Long-Term Survival in Mesothelioma Patients-Results of the German Mesothelioma Register. International Archives of Occupational and Environmental Health, 77, 191-199. https://doi.org/10.1007/s00420-003-0498-6

[16] Zucali, P.A., Simonelli, M., Michetti, G., Tiseo, M., Ceresoli, G.L., Collovà, E., Follador, A., Dico, M.L., Moretti, A., De Vincenzo, F. and Lorenzi, E. (2012) SecondLine Chemotherapy in Malignant Pleural Mesothelioma: Results of a Retrospective Multicenter Survey. Lung Cancer, 75, 360-367. https://doi.org/10.1016/j.lungcan.2011.08.011

\section{Submit or recommend next manuscript to SCIRP and we will provide best} service for you:

Accepting pre-submission inquiries through Email, Facebook, LinkedIn, Twitter, etc. A wide selection of journals (inclusive of 9 subjects, more than 200 journals)

Providing 24-hour high-quality service

User-friendly online submission system

Fair and swift peer-review system

Efficient typesetting and proofreading procedure

Display of the result of downloads and visits, as well as the number of cited articles

Maximum dissemination of your research work

Submit your manuscript at: http://papersubmission.scirp.org/

Or contact jet@scirp.org 